\title{
Chemicals of emerging concern in marine specimens of the German Environmental Specimen Bank
}

\author{
Annette Fliedner ${ }^{1 *}$ (D), Heinz Rüdel ${ }^{1}$, Annekatrin Dreyer ${ }^{2,3}$, Ulrike Pirntke ${ }^{4}$ and Jan Koschorreck ${ }^{4}$
}

\begin{abstract}
Background: Descriptor 8 of the Marine Strategy Framework Directive (MSFD) (Directive 2008/56/EC) addresses the good environmental status with regard to pollution of marine waters by chemical contaminants. Commission decision (EU) 2017/848 lays down the criteria and methodological standards on good environmental status of marine waters. Member States, in regional or subregional cooperation, shall establish lists of relevant contaminants beside those already covered by the Water Framework Directive (WFD). To provide information on emerging contaminants in marine biota, the German Environmental Specimen Bank (ESB) has compiled data of blue mussels and eelpouts from coastal sites in the North and Baltic Seas. Substances identified by the International Council for the Exploration of the Sea (ICES) as of emerging concern for the marine environment have been used as a starting point.

Results and conclusions: The study presents data of 19 emerging flame retardants and degradation products, 40 per- and polyfluoroalkyl substances (PFAS) and three cyclic volatile methylsiloxanes (cVMS). Among the emerging flame retardants, only Dec 602 was detected in all samples of 2015. Dec 604, $\mathrm{Cl}_{10}$-antiDP, 1,5-DPMA, EH-TBB, PBEB, TBP-AE, BATE, BTBPE and HBBz were constantly < limit of quantification (LOQ). Time trends were barely detected. Legacy PBDE still dominates in most samples. PFAS concentrations were usually higher in samples from the North Sea sites compared to samples from the Baltic Sea. PFOS dominated in most samples. Increasing trends over time were detected for PFNA, PFDA and PFDoDA at the Baltic Sea site and for PFDA at one North Sea site. Concentrations of the CVMS D4, D5 and D6 were below the detection limit at the ESB sampling sites. Based on the results, it should be considered to include the emerging flame retardants DP and Dec 602 and the long-chain perfluoroalkyl substances PFNA, PFDA, PFUnDA and PFDoDA in a regular monitoring in the North and Baltic Seas.
\end{abstract}

Keywords: Chemicals of emerging concern, PFAS, Dechloranes, Alternative brominated flame retardants, Cyclic volatile methylsiloxanes, Eelpout, Blue mussel, Environmental Specimen Bank, OSPAR, HELCOM

\section{Background}

According to the Marine Strategy Framework Directive (MSFD) [1], monitoring for an integrative assessment of the good environmental status has to be established. In coastal waters, the scopes of the Water Framework Directive (WFD) [2] and the MSFD overlap. Thus, any

\footnotetext{
*Correspondence: annette.fliedner@ime.fraunhofer.de

${ }^{1}$ Department Environmental Specimen Bank and Elemental Analysis, Fraunhofer Institute for Molecular Biology and Applied Ecology

(Fraunhofer IME), 57392 Schmallenberg, Germany

Full list of author information is available at the end of the article
}

monitoring with regard to Descriptor 8 of the MSFD ("Concentrations of contaminants are at levels not giving rise to pollution effects") should, where appropriate, comply with the requirements of the WFD [3]. Recommended substances for monitoring in marine environments are therefore initially those selected under the WFD [2, 4]. In addition, Member States are requested to establish in regional or subregional cooperation a list of other relevant contaminants, i.e., from offshore sources, that may lead to pollution in the marine region or subregion [5].
Springer Open

(c) The Author(s) 2020. This article is licensed under a Creative Commons Attribution 4.0 International License, which permits use, sharing, adaptation, distribution and reproduction in any medium or format, as long as you give appropriate credit to the original author(s) and the source, provide a link to the Creative Commons licence, and indicate if changes were made. The images or other third party material in this article are included in the article's Creative Commons licence, unless indicated otherwise in a credit line to the material. If material is not included in the article's Creative Commons licence and your intended use is not permitted by statutory regulation or exceeds the permitted use, you will need to obtain permission directly from the copyright holder. To view a copy of this licence, visit http://creativeco mmons.org/licenses/by/4.0/. 
Improvements in chemical analysis as well as screenings and research programs have led to the detection of new substances in the marine environment that give rise to concern because of problematic environmental properties like persistence, bioaccumulation and/or long-range transport $[6,7]$. To cope with these upcoming substances, the Hazardous Substances and Eutrophication Committee (HASEC) of the Oslo-Paris-Commission (OSPAR; Convention for the Protection of the Marine Environment of the North-East Atlantic) requested advice from the International Council for the Exploration of the Sea (ICES) to identify chemicals of emerging concern (CEC), indicate information gaps and recommend what further work or information is needed to take action [8].

In response to the request, ICES in a first step identified eight substance groups with critical chemical properties (e.g., bioaccumulation potential, persistence, toxicity) that may be of emerging concern in the marine environment, i.e., Dechlorane Plus, alternative brominated flame retardants (aBFR), organo-phosphorous flame retardants (OPFR), antifoulants, per- and polyfluoroalkyl substances (PFAS) other than PFOS and PFOA, benzotriazoles, siloxanes, and anticorrosion agents (especially those applied in offshore windmill parks). The selection based on a review of published data and recent projects that include information on new and emerging chemicals. In a report issued by ICES in 2017, data were compiled on Dechlorane Plus and dechloranes 602 and 603, as well as 16 aBFR, 27 OPFR, 25 PFAS, and two types of corrosion agents used in offshore windmill parks, whereas new antifoulants, benzotriazole compounds, and methylsiloxanes were not considered [8].

The database of the German Environmental Specimen Bank (ESB) was used to gather additional data for these substance groups. Data were available for dechloranes (including Dechlorane Plus and its degradation products, and dechloranes Dec 602, 603 and 604), 10 aBFR, 40 PFAS, and 3 cyclic volatile methylsiloxanes (cVMS).

Dechloranes were developed as substitutes for the pesticide and flame retardant Mirex [9] that was banned worldwide under the Stockholm Convention [10]. Dechlorane Plus (DP) is used as a flame retardant for instance in plastics, electric and electronic devices, and building materials $[9,11]$. It can be released to the environment during processing, use and disposal of products containing DP $[11,12]$. The main entry to the marine environment is through rivers carrying contaminated wastewater and via atmospheric transport [13]. Under Regulation (EC) No 1907/2006 (REACH) [14], DP has been classified as a substance of very high concern (SVHC) because of its persistence and bioaccumulation potential. Similar properties are also assumed for the structurally related
1,5-Dechlorane Plus mono-adduct (DPMA) [15]. Little information on production and usage is available for Dechloranes 602, 603 and 604 [8].

Alternative brominated flame retardants are a heterogeneous group of brominated substances. Their market share grew as fire safety requirements increased and the use of legacy flame retardants like polybrominated diphenyl ethers (PBDE) was more and more regulated (e.g., [10, 16-18]). Commercial Penta- and Octa-BDE mixtures, for example, were restricted in the EU in 2004 [16] and several marker congeners of these mixtures were included in Annex A of the Stockholm Convention in 2009 [10]. Alternative BFR can enter the environment during production (of the commercial product as well as of products containing aBFRs), use (i.e., release from aBFR-containing products) and disposal. In rivers, waste water treatment plants are likely sources especially of aBFR used in consumer products [19]. Some aBFRs are found in the atmosphere and may be subject to long-range transport $[6,20]$. Therefore, the main inputs to the marine environment are likely to be via rivers and atmospheric deposition. Many aBFR are persistent, bioaccumulative and/or toxic or potentially endocrine disruptive $[6,8]$.

PFAS are widely used substances, e.g., as stain repellents in papers and textiles, in non-stick cookware, firefighting foams, photographic and electronic devices, and industrial coatings [21]. They can enter the environment during manufacturing, usage and disposal whereby the main routes depend on the type of application [21, 22]. Main inputs into the marine environment are through rivers and atmospheric deposition [6, 22]. Many PFAS are persistent under environmental conditions. Their environmental behavior depends largely on their functional moiety and on the length of their carbon chain. Especially long-chain PFAS are bioaccumulative and can enrich in the food web, while short-chain PFAS tend to be mobile in sediments and waters (e.g., [23-29]). Moreover, some PFAS are toxic and/or endocrine disruptive [30, 31]. A number of long-chain PFAS (including PFOA, PFNA, PFDA, PFUnDA, PFDoDA and PFHxS) are classified as SVHC under the European $\mathrm{REACH}$ regulation [14]. PFOS and PFOA are regulated EU wide since 2006 and 2017, respectively [32, 33]. Under the Stockholm Convention [10], PFOS is listed in Annex B since 2009 and PFOA is listed in Annex A since 2019; PFHxS is proposed for listing.

Siloxanes comprise a large group of chemicals which have in common a backbone structure of silicone and oxygen atoms with side chains linked to the silicone atom. In case of the cVMS D4 (octamethylcyclotetrasiloxane), D5 (decamethylcyclopentasiloxane) and D6 (dodecamethylcyclohexasiloxane), the side chains consist of methyl groups. These siloxanes are used in biomedical 
and cosmetic applications as well as in waxes and polishes. Substantial amounts are also used for the production of siloxane polymers. They can be emitted during industrial processes or the use of products and enter the environment mainly via air and waste water [34]. Under the European REACH regulation [14, 35], D4, D5 and D6 are classified as SVHC because of their environmental persistence, bioaccumulative properties, and in the case of D4, toxicity. Moreover, D4 is assumed to be endocrine disruptive [36]. From 2020 on, D4 and D5 will be regulated EU wide [35].

The aim of the present study is to show which of these CEC are detectable and may be of relevance in the German coastal environment. Data presented were elaborated in various projects of the German ESB and refer to concentrations in blue mussels (Mytilus edulis Complex) and eelpouts (Zoarces viviparus) from coastal sampling sites in the Lower Saxony Wadden Sea, the SchleswigHolstein Wadden Sea, and the Baltic Sea Bodden National Park [37]. In some cases, available data cover time periods of up to 30 years. The focus, however, is on recent concentrations. Temporal trends are not discussed in detail but are used for the evaluation of potentially hazardous substances.

\section{Materials and methods}

\section{Sampling sites}

The ESB collects marine samples in coastal areas of the Central North Sea (FAO/ICES Division 27.4.b) and the Baltic Sea West of Bornholm (FAO/ICES Subdivision 27.3d.24). The locations of the sampling sites are shown in Fig. 1. For details, see [37].
The North Sea sites are located in the National Parks and Biosphere Reserves 'Lower Saxony Wadden Sea' (site NS 1) and 'Schleswig-Holstein Wadden Sea' (NS 2), the Baltic Sea sites (site BS) are situated in the 'Bodden National Park of Western Pomerania'. More details including possible sources of contaminations at these sites are given in $[38,39]$.

\section{Sampling and processing}

Under the ESB program, blue mussels and eelpouts are sampled regularly.

Sampling and sample processing are highly standardized. The respective protocols are documented as Standard Operating Procedures (SOP) and are laid down in a basic concept [40].

Blue mussels are collected bimonthly at the North Sea sites and every 6 months (June and November) at the Baltic Sea site [41]. Eelpout is sampled once per year in May/June before the mating season [42].

Blue mussels and eelpout filets and livers are shock-frozen at $<-130{ }^{\circ} \mathrm{C}$ immediately after sampling and biometrical characterization of the organisms. In the laboratory, the specimens (soft body of blue mussel, filets and liver of eelpout) are cryo-milled to a homogenous powder and annual composite samples are prepared for every site and specimen [43]. Aliquots of these composite samples are stored in the ESB archive at temperatures $<-130{ }^{\circ} \mathrm{C}$ in an inert atmosphere above liquid nitrogen to minimize chemical alterations $[38,44]$.

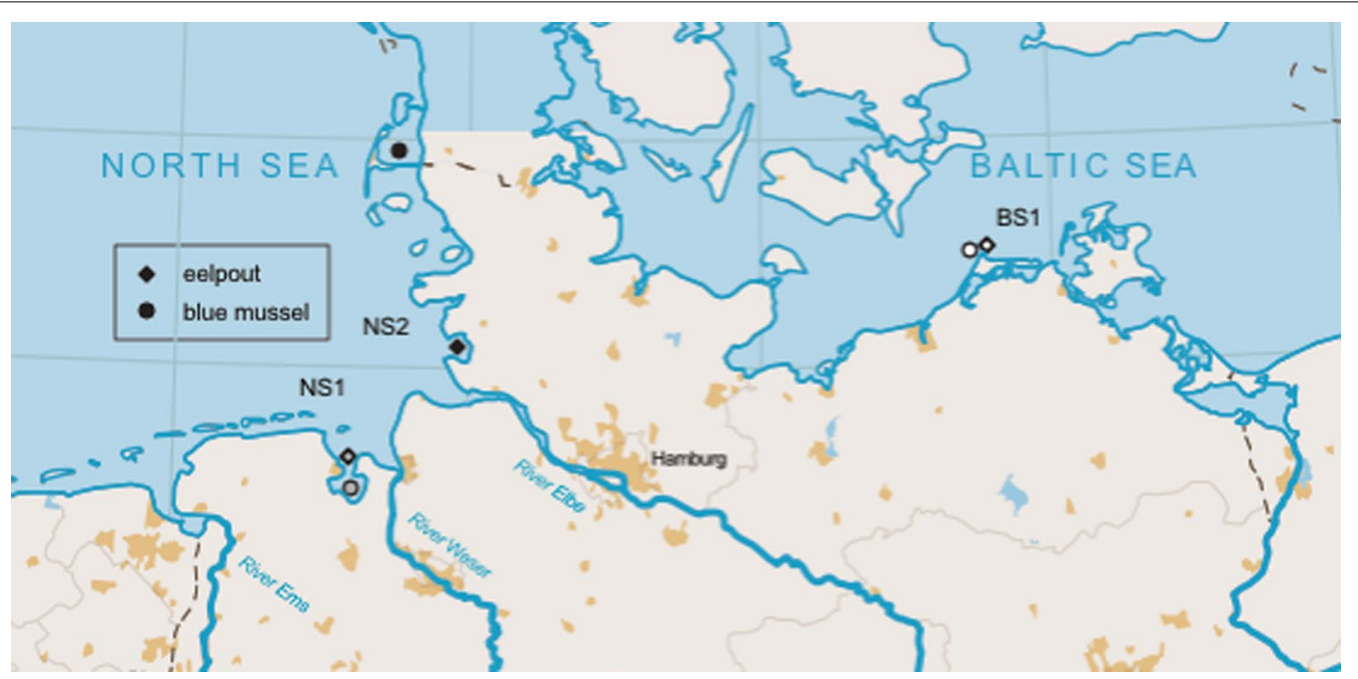

Fig. 1 Coastal sampling sites of the German Environmental Specimen Bank. NS 1: North Sea-Lower Saxony Wadden Sea; NS 2: North SeaSchleswig-Holstein Wadden Sea; BS: Baltic Sea_Bodden National Park. Sampled species: Lozenge: eelpout; Circle: blue mussel. Shading of symbols indicate that they belong to the same sampling areas, i.e., gray: NS 1; black: NS 2; white: BS 


\section{Target chemicals}

The target chemicals are summarized in Table 1 . The table includes the available data for the different ESB sampling sites. Time intervals differ between the matrices and sampling sites because the study relies on already existing data that were elaborated during different projects.

Besides the emerging FR identified by ICES [8], the structurally related compounds 1,5-DPMA, Dec 604 and the DP-degradation products $\mathrm{Cl}_{10}$-antiDP and $\mathrm{Cl}_{11}$-antiDP were analyzed. Furthermore, TBA-a fungal metabolite of the FR intermediate and fungicide 2,4,6-tribromophenol [45]-was included in the analysis. TBA has been reported in fish from various marine environments [46-50] and contributes to the overall burden of brominated compounds on organisms. For comparison, data on the WFD-relevant PBDE congeners BDE-28, $-47,-99,-100,-153$, and -154 were also included.

ICES [8] reviewed 23 PFAS that may be of emerging concern. For 13 of these substances, data were available in the ESB database (Table 1).

Time series for blue mussels ended in 2008 because PFAS concentrations were mostly below the limit of quantification (LOQ) of $0.5 \mu \mathrm{g} \mathrm{kg}^{-1}$. For eelpout, data for liver and filet are available, albeit for different periods. PFAS preferably bind to serum proteins and are typically high in well-vascularized organs like liver, blood, and kidney $[25,26,51]$. Concentrations are especially high in liver tissue as the main organ of albumin synthesis. This was the reason why PFAS were initially analyzed in liver tissue. However, when compliance monitoring came into focus the PFAS analysis switched to filet because in Germany fish filet was recommended as the matrix to be investigated in the context of the WFD [52]. Time series for liver ended in 2008/2009 but additional liver data are available for 2015 from the sampling sites NS 2 and BS. PFAS data for eelpout filet are available for the years 2003-2017. The legacy substances PFOS and PFOA were included in the data compilation as benchmarks.

The ESB database also provides data on 25 other PFAS, including fluorotelomer sulfonic acids, polyfluorinated/mixed halogenated sulfonic and phosphonic acids, perfluorooctane sulfonamides and derivatives as well as poly- and perfluoroalkyl phosphates. The data cover only 1 year (2015) and refer to eelpout livers from NS 2 and BS (Additional file 1: Table S11, S13). None of these additional 25 PFAS were detected in the samples. For the sake of clarity, they are not included in Table 1.

For the cVMS D4, D5 and D6, only data for eelpout filet from 2018 were available.

\section{Chemical analysis}

Chemical analysis and quality assurance/quality control are outlined in the Additional file 1 and in Neugebauer et al. [53] (FR), Rüdel et al. [54, 55] (PFAS) and Radermacher et al. [56] (cVMS).

In brief, for FR analyses samples of blue mussels and eelpout filet were extracted by accelerated solvent extraction (ASE) with dichloromethane: hexane followed by a multi-column clean-up and quantification based on API-GC-MS/MS in the case of emerging flame retardants and GC-MS/MS in the case of PBDE. The limits of quantification (LOQs) for all compounds were roughly in the range of $0.00004-0.139 \mu \mathrm{g} \mathrm{kg}^{-1}$ wet weight (ww) depending on substance and matrix (Additional file 1: Table S1-S6, details also found in Neugebauer et al. [53]).

PFAS were analyzed in blue mussels and eelpout filet and liver by HPLC-MS/MS [54, 55]. Samples of blue mussels and liver tissue were extracted with methyl tert.-butyl ether and analyzed by HPLC-MS/MS with atmospheric pressure ionization in the negative ion electrospray mode. LOQs were set as $0.5 \mu \mathrm{g} \mathrm{kg}^{-1} \mathrm{ww}$ (Additional file 1: Table S9-S13). Eelpout filet samples were extracted using acetonitrile, $n$-hexane, and methanol and analyzed by HPLC-MS/MS. Depending on substance, the LOQs for all PFAS were in the range of 0.05$0.5 \mu \mathrm{g} \mathrm{kg}^{-1} \mathrm{ww}$ (Additional file 1: Table S9, S10, S12). PFAS concentrations given in the ESB database refer to a mixture of straight and branched isomers.

cVMS analysis in eelpout filet included extraction with ultrasonic treatment using acetonitrile $/ n$-hexane and quantification by GC-ICP-MS/MS. Limits of detection (LODs) were $6.8 \mu \mathrm{g} \mathrm{kg}^{-1} \mathrm{ww}$ for D4, $3.1 \mu \mathrm{g} \mathrm{kg} \mathrm{g}^{-1} \mathrm{ww}$ for D5 and $8.3 \mu \mathrm{g} \mathrm{kg}^{-1} \mathrm{ww}$ for D6 (LOQs: D4: $20 \mu \mathrm{gg}^{-1}$, D5: $9.2 \mu \mathrm{g} \mathrm{kg}^{-1}$, D6: $25 \mu \mathrm{g} \mathrm{kg}^{-1}$ ). For details refer to [56].

\section{Data treatment}

All concentrations presented in the current study refer to wet weight.

Temporal trend analysis, however, was based on lipid normalized concentrations in the case of (lipophilic) flame retardants and on dry weight-normalized concentrations in the case of (hydrophobic and lipophobic) PFAS for better comparison between years. Respective normalizations are recommended by the WFD Guidance Document No. 32 of biota monitoring [57] to enhance comparability between data. Trends were analyzed using the MS-EXCEL-based software tool "LOESS Trend (Version 1.1)" developed by J. Wellmitz (German Environment Agency). The tool fits a locally weighted scatterplot smoother (LOESS; fixed window width of seven years) through the annual contaminant data followed by tests for significance of linear and non-linear 


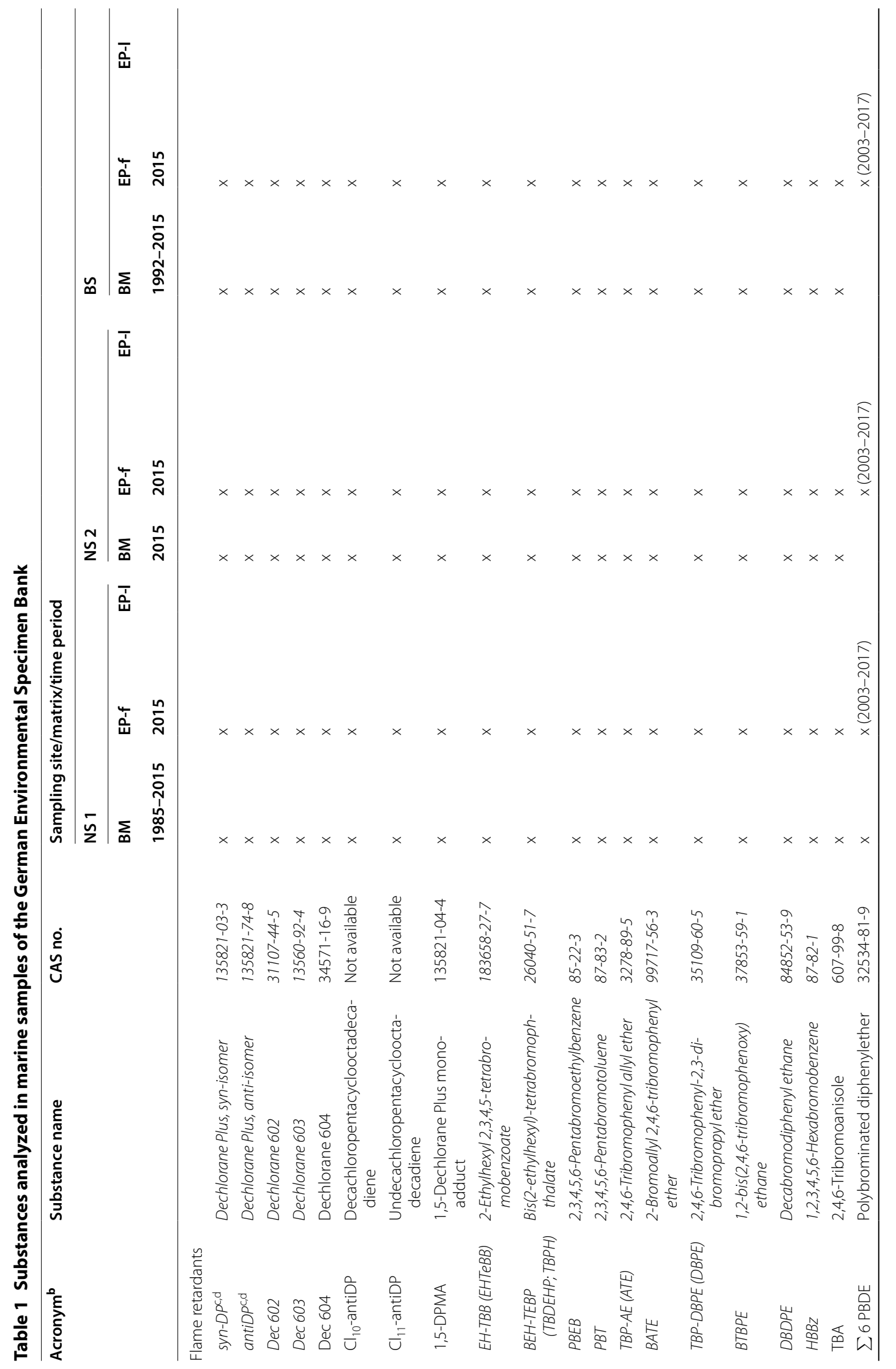




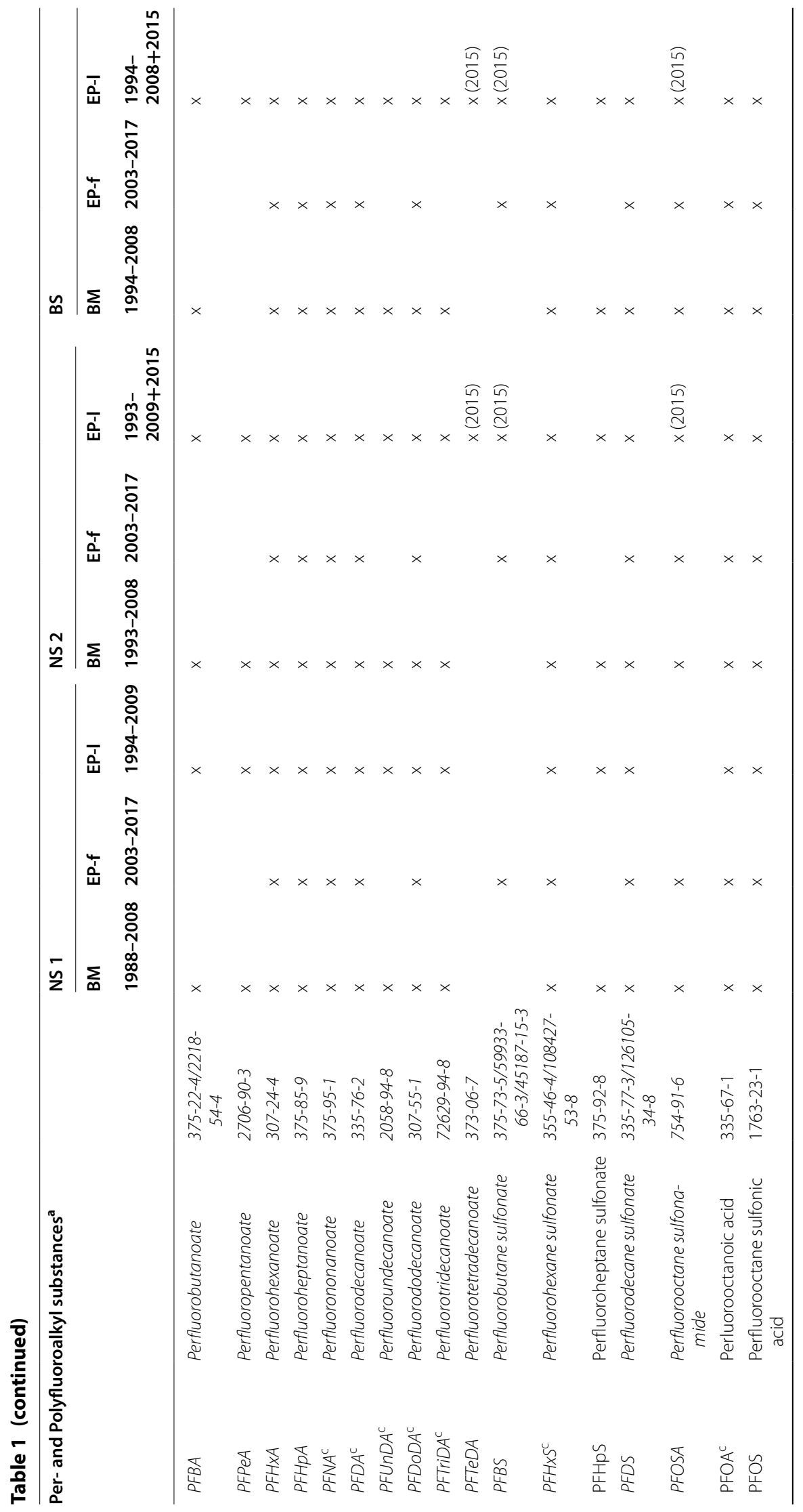




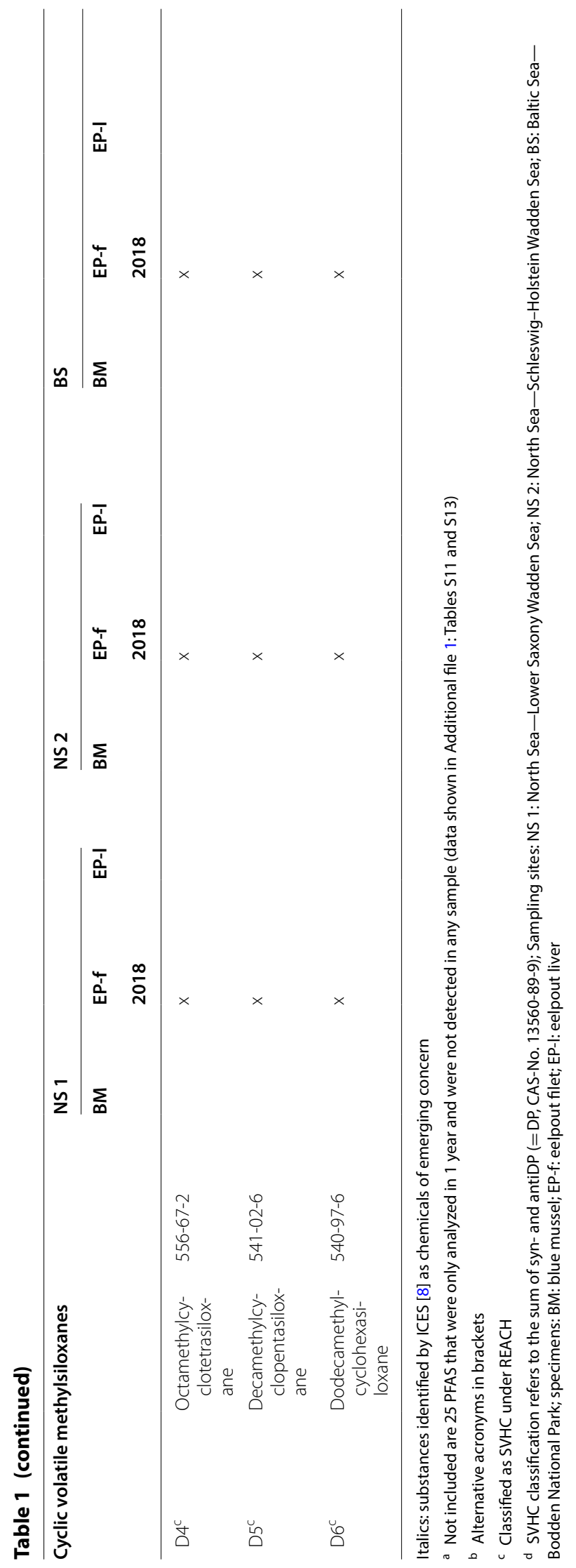


trend components by means of an Analysis of Variance (ANOVA) [58]. The tool has an integrated contrast test that allows to determine the difference between two time points (e.g., the first and the last years) based on the LOESS function and a $t$ test, provided that the span between the time points is at least 7 years. In the present study, all data on trends (increase, decrease, significance) refer to linear trends based on lipid-, respectively dry weight-normalized concentrations (see above). The results of the contrast test (as \%-change between the first and the last years) are included in the summary tables (Additional file 1: Table S14, S15).

\section{Results and discussion}

\section{Flame retardants}

Concentration ranges of FR during the entire study period are given in Additional file 1: Tables S1-S3 (dechloranes) and Additional file 1: Tables S4-S6 (aBFR + $\sum 6$ PBDE). The most recent concentrations are from 2015 and are illustrated in Fig. 2 and summarized in Table 2.

In 2015, Dec 602 was the only emerging FR detected in all samples. DP and Dec 603 were observed only in samples from the North Sea. In blue mussels from both North Sea sites, also low concentrations of the DP metabolite $\mathrm{CL}_{11}$-antiDP were detectable (Table 2). DP, Dec 602 and Dec 603 are known to bioaccumulate and biomagnify in aquatic food webs $[8,9,59,60]$. Our data confirm their presence in organisms. For Dec 602 and DP, comparable concentrations have been reported for dabs from the German Bight [61].

BEH-TEBP was detected at all three sampling sites but only in one matrix at a time (i.e., in blue mussels at NS 2 and BS, and in eelpout filet at NS 1). Concentrations were in a similar range. The bioaccumulation potential for BEH-TEBP seems to be relatively low $[62,63]$ and there is no evidence of biomagnification [64]. Comparative data for marine biota are available only for the Arctic region, where concentrations in mussels were even lower than in the present study (no comparative data for fish filet) $[13$, 64].

PBT was found in all ESB samples in 2015. At present, little data on bioaccumulation or biomagnification for PBT are available [8]. Kurt-Karakus et al. [65] observed an enrichment in the freshwater food web of Lake Ontario but no trophic level-dependence of PBT accumulation.

TBP-DBPE was detected only in blue mussels from NS 2 and eelpout from BS in 2015. TBP-DBPE is assumed to be bioaccumulative $[8,65]$. Concentrations are in the same range as those reported by Sühring et al. [61] for dabs from the German Bight.

DBDPE was found only in blue mussels from NS 2. It has to be noted, however, that the LOQ for DBPDE was relatively high (i.e., $0.04-0.14 \mu \mathrm{g} \mathrm{kg}^{-1}$, depending on matrix and year, Additional file 1: Table S4-S6; LOQ for

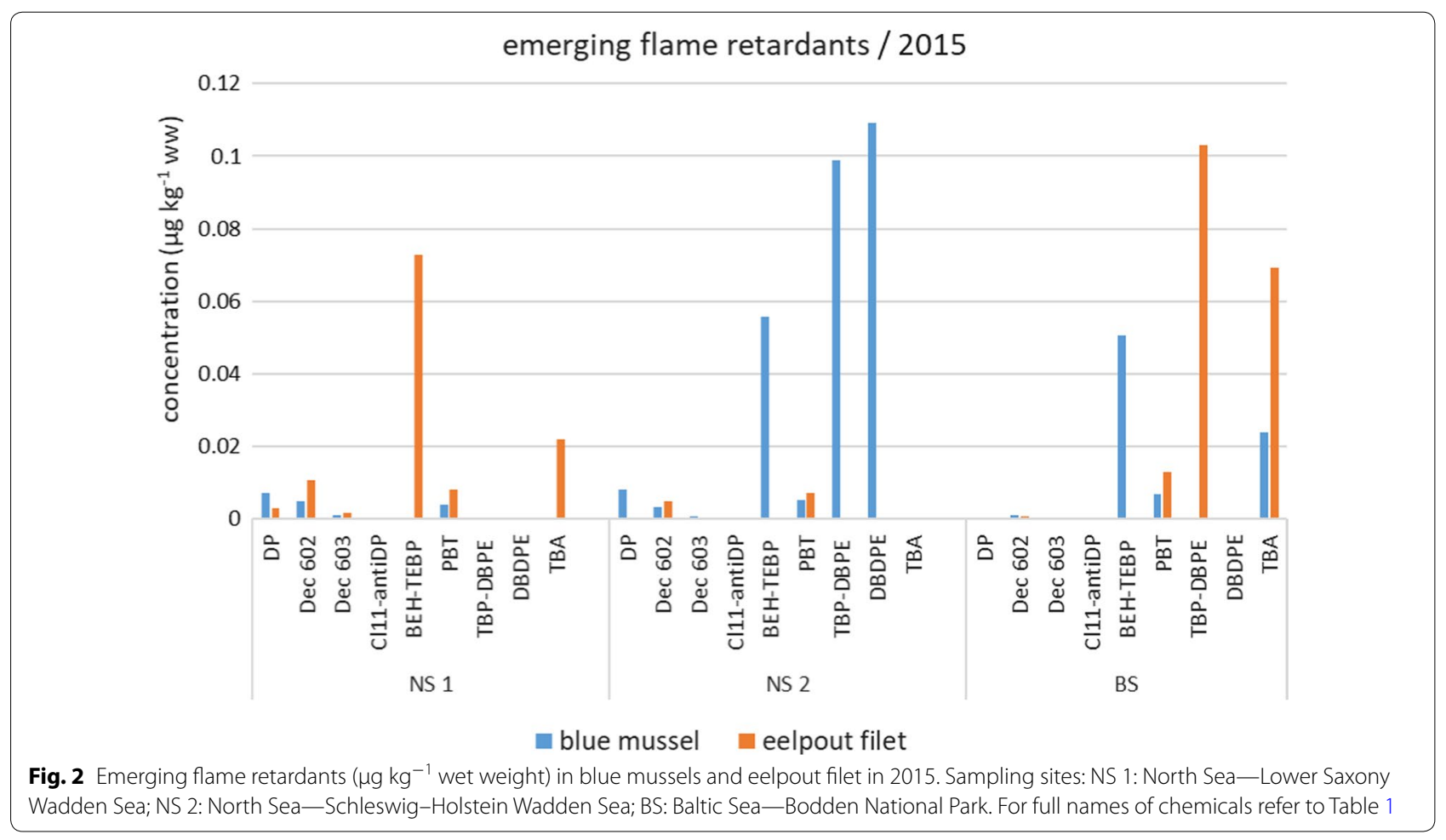


Table 2 Concentrations ( $\mu \mathrm{g} \mathrm{kg}^{-1}$ wet weight) of flame retardants in blue mussels and eelpout filet in 2015 and long-term trends

\begin{tabular}{|c|c|c|c|c|c|c|c|c|}
\hline \multirow[t]{3}{*}{ Chemical } & \multicolumn{5}{|c|}{ Blue mussel soft body } & \multicolumn{3}{|l|}{ Eelpout filet } \\
\hline & \multicolumn{2}{|l|}{ NS 1} & \multirow{2}{*}{$\begin{array}{l}\text { NS } 2 \\
\text { Conc. }\left(\mu \mathrm{kg}^{-1}\right)\end{array}$} & \multicolumn{2}{|l|}{ BS } & \multirow{2}{*}{$\begin{array}{l}\text { NS } 1 \\
\text { Conc. }\left(\mu \mathrm{g} \mathrm{kg}^{-1}\right)\end{array}$} & \multirow{2}{*}{$\begin{array}{l}\text { NS } 2 \\
\text { Conc. }\left(\mu \mathrm{gg}^{-1}\right)\end{array}$} & \multirow{2}{*}{$\begin{array}{l}\text { BS } \\
\text { Conc. }\left(\mu \mathrm{g} \mathrm{kg}^{-1}\right.\end{array}$} \\
\hline & Conc. $\left(\mu \mathrm{g} \mathrm{kg}^{-1}\right)$ & Trend & & Conc. $\left(\mu \mathrm{g} \mathrm{kg}^{-1}\right)$ & Trend & & & \\
\hline $\mathrm{DP}$ & 0.0073 & o & 0.0083 & $<\mathrm{LOQ}^{\mathrm{a}}$ & - & 0.0029 & $<\mathrm{LOQ}^{\mathrm{a}}$ & $<\mathrm{LOQ}^{\mathrm{a}}$ \\
\hline Dec 602 & 0.0048 & - & 0.0033 & 0.001 & - & 0.0107 & 0.0048 & 0.0009 \\
\hline Dec 603 & 0.001 & - & 0.0006 & $<0.0003$ & & 0.0018 & 0.0005 & $<0.0003$ \\
\hline Dec 604 & $<0.0004$ & & $<0.0005$ & $<0.0005$ & & $<0.0005$ & $<0.0005$ & $<0.0004$ \\
\hline $\mathrm{Cl}_{10}$-antiDP & $<0.0002$ & & $<0.0002$ & $<0.0002$ & & $<0.0002$ & $<0.0002$ & $<0.0002$ \\
\hline $\mathrm{Cl}_{11}$-antiDP & 0.0001 & - & 0.0001 & $<0.0001$ & & $<0.0002$ & $<0.0001$ & $<0.0001$ \\
\hline 1,5-DPMA & $<0.0001$ & & $<0.0002$ & $<0.0001$ & & $<0.0002$ & $<0.0001$ & $<0.0002$ \\
\hline EH-TBB & $<0.0111$ & & $<0.0125$ & $<0.0143$ & & $<0.0126$ & $<0.0126$ & $<0.0117$ \\
\hline BEH-TEBP & $<0.0384$ & & 0.0559 & 0.0506 & & 0.0728 & $<0.0514$ & $<0.0404$ \\
\hline PBEB & $<0.0003$ & & $<0.0003$ & $<0.0003$ & & $<0.0003$ & $<0.0003$ & $<0.0003$ \\
\hline PBT & 0.004 & + & 0.0053 & 0.0067 & o & 0.0081 & 0.0072 & 0.013 \\
\hline TBP-AE & $<0.0043$ & & $<0.0049$ & $<0.0056$ & & $<0.0049$ & $<0.0049$ & $<0.0046$ \\
\hline BATE & $<0.0014$ & & $<0.0016$ & $<0.0018$ & & $<0.0016$ & $<0.0016$ & $<0.0015$ \\
\hline TBP-DBPE & $<0.0269$ & - & 0.0989 & $<0.0345$ & - & $<0.0306$ & $<0.0306$ & 0.103 \\
\hline BTBPE & $<0.0083$ & & $<0.0093$ & $<0.0106$ & & $<0.0094$ & $<0.0094$ & $<0.0087$ \\
\hline DBDPE & $<0.0751$ & & 0.109 & $<0.0964$ & & $<0.0854$ & $<0.0855$ & $<0.0789$ \\
\hline $\mathrm{HBBz}$ & $<0.0008$ & & $<0.0009$ & $<0.0011$ & o & $<0.0009$ & $<0.001$ & $<0.001$ \\
\hline TBA & $<0.0142$ & o & $<0.016$ & 0.0239 & o & 0.0219 & $<0.0161$ & 0.0694 \\
\hline$\sum 6 \mathrm{PBDE}$ & 0.0208 & - & 0.363 & 0.0455 & o & 0.0762 & 0.0288 & 0.0371 \\
\hline
\end{tabular}

Sampling sites: NS 1: North Sea-Lower Saxony Wadden Sea; NS 2: North Sea-Schleswig-Holstein Wadden Sea; BS: Baltic Sea-Bodden National Park

Italics: quantified substances; DP: sum of syn-DP and antiDP

Trends: o: no significant linear trend; +: increase; -: decrease; blank: insufficient data, no trend calculation possible. Time intervals for trend calculations: blue mussels: NS 1: 1985-2015 BS: 1992-2015. For NS 2 and for eelpout filet, data were only available for 2015 . Trend calculation based on lipid normalized concentrations. For full names of chemicals refer to Table 1

a LOQ for syn-DP: 0.002-0.0026 $\mathrm{g} \mathrm{kg}^{-1}$, LOQ for antiDP: 0.00225-0.0029 $\mu \mathrm{g} \mathrm{kg}^{-1}$, depending on matrix (Additional file 1: Table S1-S6)

2015 in Table 2 or $0.085 \mu \mathrm{g} \mathrm{kg}-1$ for mussels from NS 2). DBDPE bioaccumulates and biomagnifies in aquatic ecosystems $[8,66]$. The fact that DBDPE was detected only in blue mussels but not in eelpouts might reflect different exposures at the NS 2 sampling sites for blue mussels and eelpouts (Fig. 1).

TBA seems to be more relevant in the Baltic Sea. In 2015, it was detected in blue mussels and eelpout from BS with comparatively high concentrations in eelpout filet. By contrast, levels were $<$ LOQ in blue mussels from both North Sea sites and in eelpout from NS 2; concentrations in eelpout from NS 1 were quite low. TBA has been frequently detected in marine invertebrates, fish and mammals [46, 48-50, 61].

Dec 604, $\mathrm{Cl}_{10}$-antiDP, 1,5-DPMA, EH-TBB, PBEB, TBP-AE, BATE, BTBPE and HBBz were not quantified in any sample in 2015.

For comparison purposes, the concentrations of the WFD-relevant PBDE congeners BDE-28, -47, -99, $-100,-153$ and $-154\left(\sum 6 \mathrm{PBDE}\right)$ were included in the study. Concentrations of $\sum 6$ PBDE in 2015 are shown in Table 2; the congener data are summarized in Additional file 1: Table S7.

Concentrations of $\sum 6$ PBDE were mostly higher than those of emerging flame retardants. The only exceptions are BEH-TEHP, TBP-DBPE and TBA. For BEHTEHP, concentrations in blue mussels from BS and in eelpout from NS 1 were similar to those of $\sum 6$ PBDE. Levels of TBP-DBPE were higher than $\sum 6$ PBDE concentrations in eelpout filet from NS 2. Concentrations similar to those of $\sum 6$ PBDE were also observed for TBA in samples from BS.

In eelpout filet, some of the emerging FR were within the same concentration range as single BDE congeners (Additional file 1: Table S8): at the North Sea site NS 1, BEH-TEBP concentrations in eelpout filet were slightly higher than those of BDE-47, while Dec 602 was in the same range as BDE-99, -100 and -154. In eelpout from 
NS 2, levels of PBT and BDE-154 as well as of Dec 602 and BDE-153 are within the same range.

The results demonstrate that some of the emerging flame retardants identified by ICES [8] (i.e., Dec 602, BEH-TEHP, TBP-DBPE, PBT, TBA) are present in marine biota from German coastal sites at concentrations that are similar to those of legacy PBDE.

Similar findings have been reported for freshwater fish from differently contaminated rivers in Spain, where Dec 602 levels were comparable to those of BDE100 or BDE-47 or even to the sum PBDE congeners in whole fish [67]. Pena-Abaurrea et al. [50] found levels of TBA in muscle tissue of tuna from the Mediterranean Sea that were in the same range as BDE-154.

The data reflect the growing production and use of alternative FR in the past years that was triggered by the increasing regulation of the legacy FR $[9,18]$.

Looking at the long-term data, decreasing temporal trends $(p \leq 0.01)$ are observed for Dec 602, Dec 603, $\mathrm{Cl}_{11}$-antiDP and TBP-DBPE in blue mussels from NS 1, and for DP, Dec 602 and TBP-DBPE in blue mussels from BS (Table 2, Additional file 1: Table S14). None of these flame retardants are restricted in the EU to date. It can only be speculated that voluntary phase-outs and/or shifts to other less problematic FR are responsible for the observed decreases.
Increases over time $(p<0.01)$ were only observed for PBT in blue mussels from NS 1.

Concentrations of $\sum 6$ PBDE decreased more or less steadily in blue mussels and eelpout filet from NS 1 and in eelpout filets from NS 2 and BS (all $p<0.01$ ). The blue mussel data show that $\sum 6$ PBDE already decreased before the commercial Penta- and Octa-BDE mixtures were regulated in the EU in 2004 [16] (no corresponding statement can be made for eelpouts, as the time series only begin in 2003). This possibly reflects the voluntary phase-out of commercial Penta-BDE by industrial users in Germany already in 1986 [68].

\section{Per- and polyfluoroalkyl substances}

The available data for PFAS are summarized in Additional file 1: Tables S9-S13. Figure 3 shows the concentrations of emerging PFAS in eelpout filet and liver in 2015. Table 3 summarizes the 2015 data and includes also PFOA and PFOS and the results of the trend analysis.

In 2015, concentrations in eelpout livers were mostly< LOQ $\left(0.3 \mu \mathrm{g} \mathrm{k}^{-1}\right)$ (Table 3$)$. However, relatively high concentrations were observed for PFNA, PFDA and PFUnDA in liver samples from BS and for PFOSA in samples from NS 2 (Fig. 3). The liver concentrations were considerably higher than in the corresponding filet samples, which is attributable to the preferential binding of PFAS to serum proteins [25].

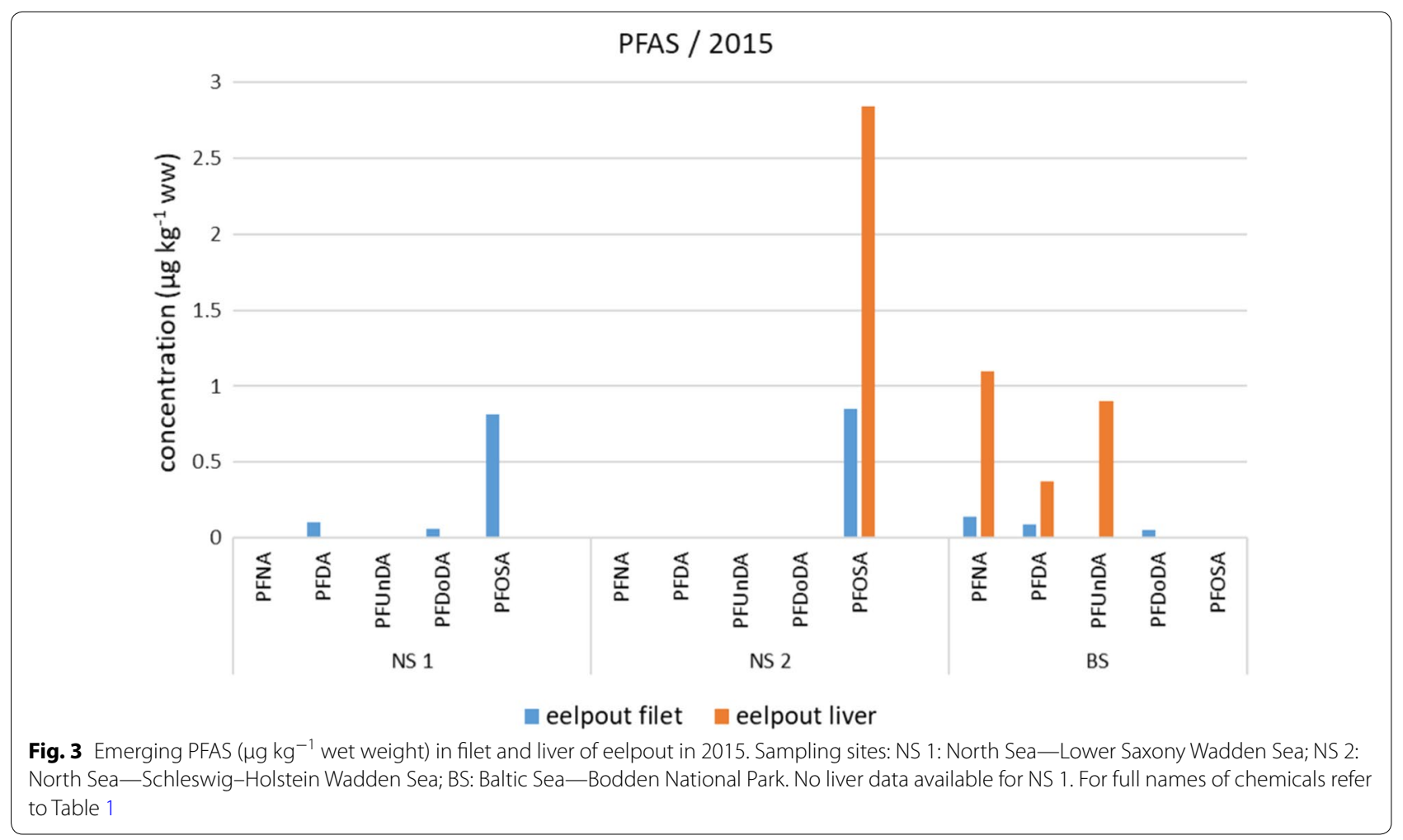


Table 3 Concentrations ( $\mu \mathrm{g} \mathrm{kg}^{-1}$ wet weight) of PFAS in eelpout in 2015 and long-term trends

\begin{tabular}{|c|c|c|c|c|c|c|c|c|}
\hline \multirow[t]{3}{*}{ Chemical } & \multicolumn{6}{|l|}{ Eelpout filet } & \multicolumn{2}{|l|}{ Eelpout liver } \\
\hline & \multicolumn{2}{|l|}{ NS 1} & \multicolumn{2}{|l|}{ NS 2} & \multicolumn{2}{|l|}{ BS } & \multirow{2}{*}{$\begin{array}{l}\text { NS } 2 \\
\text { Conc. }\left(\mu \mathrm{g} \mathrm{kg}^{-1}\right)\end{array}$} & \multirow{2}{*}{$\begin{array}{l}\text { BS } \\
\text { Conc. }\left(\mu \mathrm{kg}^{-1}\right)\end{array}$} \\
\hline & Conc. $\left(\mu \mathrm{g} \mathrm{kg}^{-1}\right)$ & Trend & Conc. $\left(\mu \mathrm{g} \mathrm{kg}^{-1}\right)$ & Trend & Conc. $\left(\mu \mathrm{g} \mathrm{kg}^{-1}\right)$ & Trend & & \\
\hline PFBA & & & & & & & $<0.300$ & $<0.300$ \\
\hline PFPeA & & & & & & & $<0.300$ & $<0.300$ \\
\hline PFHXA & $<0.053$ & & $<0.058$ & & $<0.050$ & & $<0.300$ & $<0.300$ \\
\hline PFHpA & $<0.053$ & & $<0.057$ & & $<0.050$ & & $<0.300$ & $<0.300$ \\
\hline PFNA & $<0.053$ & & $<0.057$ & & 0.137 & + & $<0.300$ & 1.1 \\
\hline PFDA & 0.103 & + & $<0.057$ & o & 0.089 & + & $<0.300$ & 0.37 \\
\hline PFUnDA & & & & & & & $<0.300$ & 0.90 \\
\hline PFDoDA & 0.056 & & $<0.057$ & & 0.05 & + & $<0.300$ & $<0.300$ \\
\hline PFTriDA & & & & & & & $<0.300$ & $<0.300$ \\
\hline PFTeDA & & & & & & & $<0.300$ & $<0.300$ \\
\hline PFBS & $<0.080$ & & $<0.085$ & & $<0.075$ & & $<0.300$ & $<0.300$ \\
\hline PFHxS & $<0.080$ & & $<0.085$ & & $<0.075$ & & $<0.300$ & $<0.300$ \\
\hline PFHpS & & & & & & & $<0.300$ & $<0.300$ \\
\hline PFDS & $<0.080$ & & $<0.085$ & & $<0.075$ & & $<0.300$ & $<0.300$ \\
\hline PFOSA & 0.814 & - & 0.853 & - & $<0.050$ & & 2.84 & $<0.300$ \\
\hline PFOA & $<0.053$ & & $<0.057$ & & $<0.050$ & & $<0.300$ & $<0.300$ \\
\hline PFOS & 0.921 & o & 0.202 & - & 0.487 & o & 3.7 & 9.1 \\
\hline
\end{tabular}

Sampling sites: NS 1: North Sea-Lower Saxony Wadden Sea; NS 2: North Sea-Schleswig-Holstein Wadden Sea; BS: Baltic Sea-Bodden National Park (Baltic Sea) Italics: quantified substances; blank: no data

Trends: o: no significant linear trend, +: increase, -: decrease; blank: insufficient data, no trend calculation possible. Time intervals for trend calculations: eelpout filet: 2003-2017; eelpout liver: NS 2: 1993-2009, BS: 1994-2008. For full names of chemicals refer to Table 1

The filet data at NS 2 and BS mirror the respective liver data. The only exceptions were PFUnDA and PFDoDA in fish from BS. For PFUnDA, no 2015 data in eelpout filet from BS are available. In the case of PFDoDA, however, the lower sensitivity of the analytical method applied to liver tissue may have led to the observed discrepancy (see Additional file 1: section 'Chemical analysis' and Tables S9-S13).

PFAS with carbon chain lengths $<8$ carbon atoms were not detected in any sample. This reflects the lower bioaccumulation potential of short-chain PFAS compared to PFAS with long carbon chains [69, 70].

The legacy compound PFOS-included here as benchmark-was still detected in all samples in 2015 in mostly highest concentrations (Table 3). It dominated clearly in eelpout filet and liver from BS. At the North Sea sites, however, PFOS levels were in the same range as PFOSA in both eelpout filet and liver. By contrast, the concentration of the legacy compound PFOA in all samples was below the respective LOQ of $0.05-0.30 \mu \mathrm{g} \mathrm{kg}^{-1}$.

Long-term data show significant decreasing trends for PFOSA in eelpout filet at both North Sea sites (both $p<0.01$ ) and for PFOS in eelpout filet from NS 2 $(p=0.01)$. No respective trends were observed at the other sites (Table 3, Additional file 1: Table S15).
Increasing trends were detected for PFDA in eelpout filet at NS 1 and BS (both $p<0.01$ ) and for PFNA $(p=0.01)$ and PFDoDA $(p=0.02)$ at BS (Table 3, Additional file 1: Table S15). At BS, the trends for PFNA and PFDA were not steady (Additional file 1: Fig. S1). The highest concentrations were detected around 2013. Whether the lower PFNA and PFDA concentrations toward the end of the study period actually indicate a decrease in exposure cannot be answered conclusively by the data. However, they may be related to the US EPA PFOA Stewardship Program that aimed at the global phasing out of PFOA, its precursors and related higher homolog chemicals by 2015 [22, 71].

Comparative published data for PFAS in liver samples from marine fish are available, e.g., for cod sampled in 2008 and 2009 at 15 sites around Norway [72]: PFOS was frequently detected in cod livers (in 144 of 200 samples), whereas PFHxS, PFOSA, PFOA, PFNA, PFDA, PFUnDA, PFDoDA and PFTriDA were present in individual liver samples only. PFPeA, PFBA, PFHxA, PFHpA, PFTeDA, PFBS and PFDS were not detected at all. Reported concentrations were always higher than those detected at the ESB sites in the respective years. Danielsson et al. [73] report PFAS concentrations in livers of eelpout, herring and perch from differently polluted sites along 
the Swedish coast in 2011. PFOS and PFDA concentrations in eelpout livers were slightly higher compared to the samples from the ESB site BS in the same year. For herring livers, decreasing trends since 2007/2008 were observed for PFOS, PFOSA, PFDA, PFUnDA and PFDoDA at many sites along the Swedish coast [74].

PFAS concentrations in eelpout filet from the Swedish coast were mostly in the same range as our data from BS [73, 75]. PFOS dominated in all samples. Concentrations of PFOA, PFNA and PFDA in Swedish eelpout samples were slightly lower than in eelpout samples from $\mathrm{BS}$ in the same year. As in eelpout filet from BS, PFHxA, PFHpA, PFBS, PFHxS and PFDS were not detected in any sample from Sweden. Similarly, PFBA and PFBS were not detected in perch and herring from Finnish coastal waters sampled between 2014 and 2016 [76].

\section{Methylsiloxanes}

The cVMS D4, D5 and D6 were not detected in any eelpout filet sample from 2018 (all $<$ LOD, i.e., $\mathrm{D} 4<6.8 \mu \mathrm{g} \mathrm{kg}^{-1}$, D5 $<3.1 \mu \mathrm{g} \mathrm{kg}^{-1}$ and D6 $<8.3 \mu \mathrm{g} \mathrm{kg}^{-1}$ ).

Comparative wet weight concentrations of siloxanes in marine fish are, for instance, available from coastal waters of Norway and from the Baltic Sea. In whole fish samples of eelpout from the inner Oslo Fjord, Powell et al. [77] detected concentrations in the range of $<3.7-2.3 \mu \mathrm{g} \mathrm{kg}-1$ (D4), 14.4-72.8 $\mu \mathrm{g} \mathrm{kg}^{-1}$ (D5) and $<4.7-6.67 \mu \mathrm{g} \mathrm{kg}{ }^{-1}$ (D6). Filet concentrations are available for herring from the Baltic Sea (D4: $<4.4-0.5 \mu \mathrm{g} \mathrm{kg}^{-1}$; D5: $10-21 \mu \mathrm{g} \mathrm{kg}^{-1}$; D6: 2-5.4 $\mu \mathrm{g} \mathrm{kg}^{-1}$ ) [78]. The reported concentrations were partly lower than the LODs achieved here.

Comparison between the North Sea and the Baltic Sea sites To determine whether there are fundamental differences in the type of contamination between the German coastal sites in the North Sea and the Baltic Sea, data of the sites NS 1 and NS 2 were compared to those of BS.

For FR, the most striking difference was the higher contribution of $\sum 6$ PBDE to the total FR burdens of blue mussels and eelpout filets at the North Sea sites (Table 2). In 2015, the share of $\sum 6$ PBDE in blue mussels was $55 \%$ at NS 1 and $56 \%$ at NS 2 compared to $36 \%$ at BS. In eelpout filet, the respective fractions were $39 \%$ at NS 1 and $70 \%$ at NS 2 compared to only $17 \%$ at BS.

These findings indicate that legacy PBDE still play a major role in the contamination of coastal sites in the North Sea, whereas this is less evident at the Baltic Sea site.

Clear concentration differences (factors of about 2-12) between the sampling sites in the North and the Baltic Seas were observed for DP, Dec 602 and Dec 603 , all of which were higher in biota samples from the North Sea sites. Levels of PBT and TBA were higher in blue mussels and eelpout filet from BS (factors of about 1.5-4) than in samples from the North Sea (Fig. 2, Table 2). For all other substances, differences between the North Sea sites and the Baltic Sea site were not consistent. There are, however, also differences between both North Sea sites indicating that the exposure differs also between the Lower Saxony Wadden Sea (NS 1) and the Schleswig-Holstein Wadden Sea (NS 2). In 2015, FR contamination of eelpout filet was higher at NS 1 compared to NS 2, whereas blue mussel contamination was higher at NS 2 (Fig. 2, Table 2). DBDPE and TBP-DBPE were detected only in samples from NS 2.

Patterns of emerging FR in 2015 are illustrated in Fig. 4. The concentrations of some FR especially in blue mussels were quite low and near the respective LOQ. They were nevertheless included in Fig. 4 to acknowledge their presence at the respective sampling site.

Particularly noticeable is the dominance of BEHTEBP in blue mussels from BS and the high share of TBA, both of which are not reflected in mussels from the North Sea sites. In eelpout filet, the share of TBPDBPE and TBA was higher at BS than at the North Sea sites, whereas the share of Dec 602 was lower.

When comparing the long-term trends of FR contamination at the different sampling sites, similar

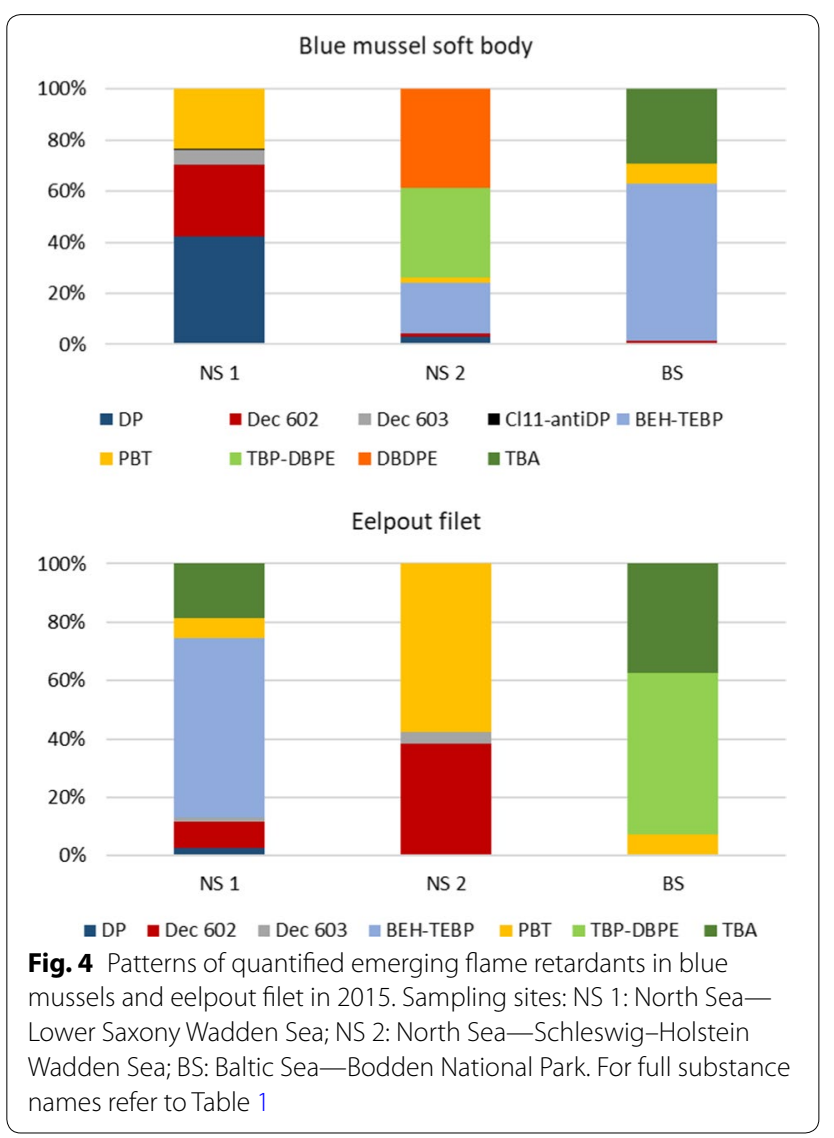


(decreasing) trends can be observed for Dec 602 and TBP-DBPE in blue mussels from NS 1 and BS. Concentrations of $\sum 6$ PBDE decreased in eelpout filet from all three sites (Table 2, Additional file 1: Table S14).

Differences in long-term trends between the sites were observed for PBT (increase in blue mussels from NS 1 but no significant trends at BS), Dec 603 and $\mathrm{CL}_{11}$-antiDP (both decreased in blue mussels from NS 1 but not at BS) and for DP (decrease at BS but no significant trend at NS 1).

Regarding PFAS, high concentrations of the legacy compound PFOS were still detected in both North Sea and Baltic Sea biota samples. In 2015, eelpout samples from BS were dominated by PFOS with shares of $64 \%$ in eelpout filet and $79 \%$ in eelpout liver. The respective fractions were smaller in eelpout samples from the North Sea sites (i.e., in eelpout filet 49\% (NS 1) and 19\% (NS 2), and in eelpout liver 57\% (NS 2; no data for NS 1)).

A striking difference between eelpout samples from the North and the Baltic Sea sites is the higher share of PFOSA at the North Sea sites in 2015 (Fig. 5). By contrast, in eelpout from BS comparatively higher shares of PFNA, PFDA and PFUnDA (analyzed only in liver) were detected.

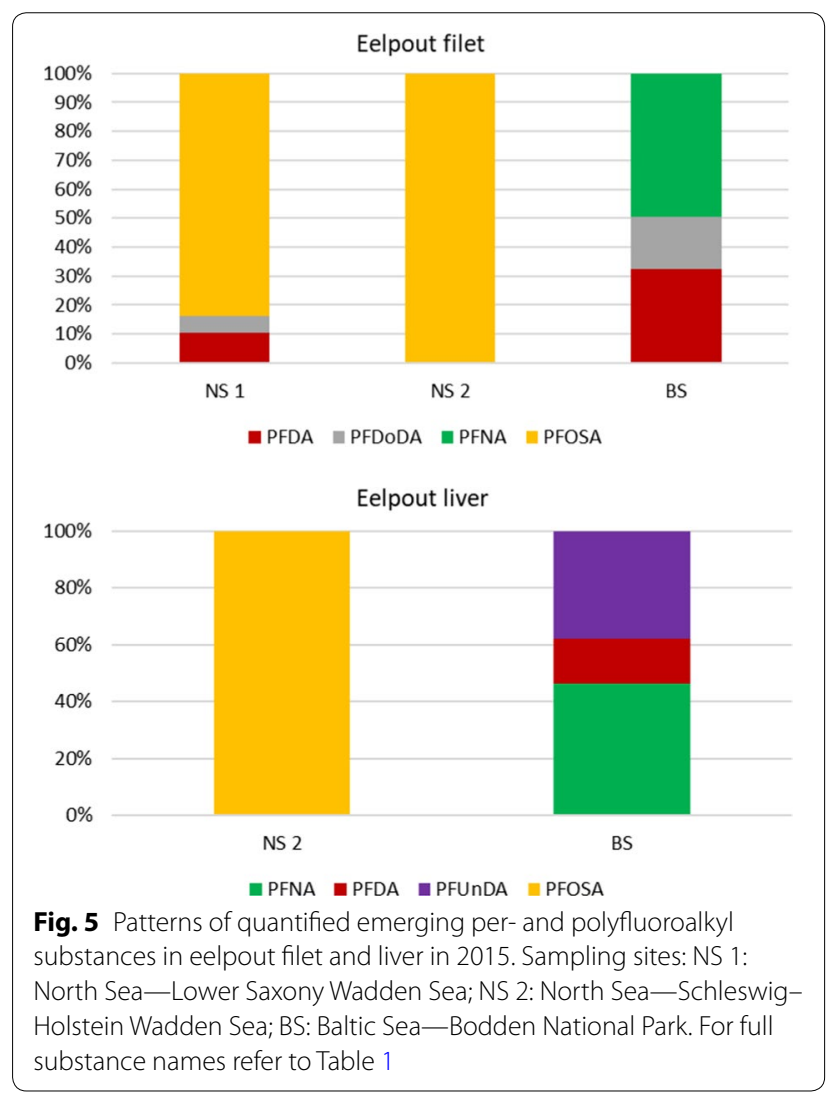

The concentrations of some PFAS detected in 2015 were quite low and close to the respective LOQ. They were nonetheless included in Fig. 5 to indicate their presence at the respective site.

Comparing the long-term trends of PFAS (Table 3, Additional file 1: Table S15) reveals that at both North Sea sites levels of PFOSA decreased in eelpout filet during the study periods, whereas no respective trends were observed at BS. On the other hand, an increasing trend for PFNA and PFDoDA could only be observed at the sampling site BS. PFDA increased significantly in eelpout filet from NS 1 and BS.

\section{Summary and conclusions}

The aim of the study was to provide data from the coastal sampling sites of the ESB for chemicals that may be of emerging concern for the marine environment. For reference purposes, also data of legacy compounds were included in the data analysis. The assessment of the potential hazards posed by the substances examined here is based on the concentrations and temporal trends of these chemicals in biota samples only. Relatively high concentrations that go hand in hand with increasing temporal trends are assumed to be particularly problematic.

Our data show that, despite being restricted worldwide since 2009 [79], the legacy compounds $\sum 6$ PBDE and PFOS still dominate in the majority of the samples. In 2015, it was only in blue mussels and eelpout filet from the Baltic Sea site and in eelpout filet from the North Sea site NS 1 that concentrations of some emerging flame retardants were within the same range or even higher than $\sum 6$ PBDE (i.e., BEH-TEBP in blue mussels and TBP-DBPE in eelpout filet from BS, and BEH-TEBP in eelpout filet from NS 1). For PFAS, only PFOSA was detected in concentration ranges comparable to those of PFOS in recent years (i.e., in eelpout filet from both North Sea sites).

Comparatively high concentrations in biota combined with increasing temporal trends were hardly observed. None of the emerging FR met these criteria. In 2015, concentrations of BEH-TEBP, TBP-DBPE and DBDPE were comparatively high but for none of these compounds, increasing trends over time were observed. By contrast, PBT concentrations increased at NS 1 but levels in 2015 were low.

However, even though concentrations were relatively low in 2015, DP may be of concern because of its classification as SVHC under the REACH regulation [14]. Furthermore, Dec 602 may be of relevance because it was present in all analyzed samples.

In the case of PFAS, relatively high concentrations combined with increasing trends were detected for 
PFNA, PFDA and PFDoDA at the Baltic Sea site BS. Levels of PFUnDA were quite high in eelpout livers in 2015 and indicate an increase over time (no trend analysis possible because of insufficient data; no 2015-data for PFUnDA in filet). PFDA and PFDoDA were also detected in eelpout filet from NS 1 along with an increasing trend for PFDA.

Since PFNA, PFDA, PFUnDA and PFDoDA are classified as SVHC under the REACH regulation [14], these chemicals may be of emerging concern at all investigated sites.

The cVMS D4, D5 and D6 seem to play only a minor role at the ESB sampling sites. Currently, the database for these substances in marine ESB samples is limited.

In summary, our results indicate that at least the emerging flame retardants DP and Dec 602 and the longchain perfluoroalkyl substances PFNA, PFDA, PFUnDA, and PFDoDA should be further considered for monitoring in the North and the Baltic Sea, e.g., when establishing lists of relevant contaminants through regional or subregional cooperation.

\section{Supplementary information}

Supplementary information accompanies this paper at https://doi. org/10.1186/s12302-020-00312-x.

Additional file 1. Details of chemical analysis and supplemental results.

\section{Abbreviations}

aBFR: Alternative brominated flame retardants; ASE: Accelerated solvent extraction; antiDP: Dechlorane Plus, anti-isomer; API-GC-MS/MS: Atmospheric pressure interface coupled to gas chromatography and tandem mass spectrometry; BATE: 2-Bromoallyl 2,4,6-tribromophenyl ether; BEH-TEBP: Bis(2-ethylhexyl)-tetrabromophthalate, also known as BEHTBP; BS: Baltic Sea: ESB sampling site in the Bodden National Park of Western Pomerania; BTBPE: 1,2-Bis(2,4,6-tribromophenoxy)ethane; CEC: Chemicals of emerging concern; $\mathrm{Cl}_{10}$-antiDP: Decachloropentacyclooctadecadiene; $\mathrm{Cl}_{11}$-antiDP: Undecachloropentacyclooctadecadiene; cVMS: Cyclic volatile methylsiloxanes; DBDPE: Decabromodiphenyl ethane; Dec: Dechlorane; DP: Dechlorane Plus; D4: Octamethylcyclotetrasiloxane; D5: Decamethylcyclopentasiloxane; D6: Dodecamethylcyclohexasiloxane; DPMA: 1,5-Dechlorane Plus mono-adduct, also known as 1,5-DPMA; EH-TBB: 2-Ethylhexyl-2,3,4,5-tetrabromobenzoate, also known as EHTeBB; ESB: Environmental Specimen Bank; EU: European Union; FAO: Food and Agriculture Organization of the United Nations; FR: Flame retardant; HASEC: Hazardous Substances and Eutrophication Committee; HBBz: 1,2,3,4,5,6-Hexabromobenzene; HBCDD: Hexabromocyclododecane; HELCOM: Baltic Marine Environment Protection Commission; HPLC-MS-MS: High-performance liquid chromatography coupled to tandem mass spectrometry; ICES: International Council for the Exploration of the Sea; LOD: Limit of detection; LOESS: Locally weighted scatterplot smoother/ trend tool; LOQ: Limit of quantification; MSFD: Marine Strategy Framework Directive; NS 1: North Sea 1: ESB sampling site in the Lower Saxony Wadden Sea; NS 2: North Sea 2: ESB sampling site in the Schleswig-Holstein Wadden Sea; OPFR: Organo-phosphorous flame retardants; OSPAR: Convention for the Protection of the Marine Environment of the North-East Atlantic; PBDE: Polybrominated diphenyl ethers, here: sum of BDE-28, $-47,-99,-100,-153$ and -154; PBEB: 2,3,4,5,6-Pentabromoethylbenzene; PBT: 2,3,4,5,6-Pentabromotoluene; PFAS: Per- and polyfluoroalkyl substances; PFBA: Perfluorobutanoate; PFPeA: Perfluoropentanoate; PFHxA: Perfluorohexanoate; PFHpA: Perfluoroheptanoate; PFNA: Perfluorononanoate; PFDA: Perfluorodecanoate; PFUnDA:
Perfluoroundecanoate; PFDoDA: Perfluorododecanoate; PFTeDA: Perfluorotetradecanoate; PFTrDA: Perfluorotridecanoate; PFBS: Perfluorobutane sulfonate; PFHXS: Perfluorohexane sulfonate; PFDS: Perfluorodecane sulfonate; PFOSA: Perfluorooctane sulfonamide; PFOA: Perfluorooctanoic acid; PFOS: Perfluorooctane sulfonic acid; REACH: Registration, Evaluation, Authorisation and Restriction of Chemicals (EU Regulation); SOP: Standard Operating Procedures; SVHC: Substance of very high concern; Syn-DP: Dechlorane Plus, syn-isomer; TBA: 2,4,6-Tribromoanisole; TBP-AE: 2,4,6-Tribromophenyl allyl ether, also known as ATE; TBP-DBPE: 2,4,6-Tribromophenyl-2,3-dibromopropyl ether, also known as DBPE; WDF: Water Framework Directive; ww: Wet weight.

\section{Acknowledgements}

This study was funded by the German Environmental Specimen Bank program. J. Wellmitz from the German Environment Agency is thanked for the provision of the LOESS trend tool software. We acknowledge the dedicated work of all members of the ESB teams at the Environment Agency, Eurofins, Fraunhofer IME, and Trier University The study was contracted for the Environmental Research of the Federal Ministry for the Environment, Nature Conservation, and Nuclear Safety in Germany.

\section{Authors' contributions}

$\mathrm{AF}$ and $\mathrm{HR}$ are responsible for the data compilation, interpretation of the data and drafting of the manuscript. AD provided the data of emerging flame retardants and was significantly involved in revising the manuscript. JK and UP initiated the contribution, provided relevant background information and were involved in revising the manuscript. All authors read and approved the final manuscript.

\section{Funding}

The preparation of this manuscript was not funded by third parties.

\section{Availability of data and materials}

Data are original data from the German Environmental Specimen Bank or are from the references given. The data on dechloranes, PBDE and PFAS are freely available on the website of the ESB (http://www.umweltprobenban k.de/en). Recent data of aBFR are given in Dreyer et al. (2019) Recent findings of halogenated flame retardants (HFR) in the German and Polar environment. Environ Pollut 253:850-863

\section{Ethics approval and consent to participate}

Not applicable.

\section{Consent for publication \\ Not applicable.}

\section{Competing interests}

The authors declare that they have no competing interests.

\section{Author details}

${ }^{1}$ Department Environmental Specimen Bank and Elemental Analysis, Fraunhofer Institute for Molecular Biology and Applied Ecology (Fraunhofer IME), 57392 Schmallenberg, Germany. ${ }^{2}$ Eurofins GfA GmbH, 21107 Hamburg, Germany. ${ }^{3}$ Present Address: ANECO Institut für Umweltschutz, 21079 Hamburg, Germany. ${ }^{4}$ German Environment Agency (Umweltbundesamt), 06813 Dessau-Rosslau, Germany.

Received: 1 December 2019 Accepted: 14 February 2020

Published online: 02 March 2020

\section{References}

1. EC (2008) Directive 2008/56/EC of the European Parliament and of the Council of 17 June 2008 establishing a framework for community action in the field of marine environmental policy (Marine Strategy Framework Directive), Official Journal of the European Union, L164/19. http:// eur-lex.europa.eu/legal-content/EN/TXT/PDF/?uri=CELEX:32008L0056 \&from $=E N$. Accessed 25 July 2008

2. EC (2000) Directive $2000 / 60 / E C$ of the European Parliament and of the Council of 23 October 2000 establishing a framework for Community action in the field of water policy, Official Journal of the European 
Communities, L327/1. http://eur-lex.europa.eu/resource.html?uri=cella r:5c835afb-2ec6-4577-bdf8-756d3d694eeb.0004.02/DOC_18forma $\mathrm{t}=$ PDF. Accessed 22 Dec 2000

3. Tornero V, Hanke G (2016) Chemical contaminants entering the marine environment from sea-based sources: a review with a focus on European seas. Mar Pollut Bull 112:17-38

4. EC (2013) Directive 2013/39/EU of the European Parliament and of the Council of 12 August 2013 amending Directives 2000/60/EC and 2008/105/EC as regards priority substances in the field of water policy, Official Journal of the European Union, L226/1. http://eur-lex.europa.eu/ LexUriServ/LexUriServ.do?uri=OJ:L:2013:226:0001:0017:EN:PDF. Accessed 24 Mar 2013

5. EC (2017) Commission Decision (EU) 2017/848 of 17 May 2017 laying down criteria and methodological standards on good environmental status of marine waters and specifications and standardised methods for monitoring and assessment, and repealing Decision 2010/477/EU, Official Journal of the European Union, L125/43. https://eur-lex.europa.eu/legal -content/EN/TXT/PDF/?uri=CELEX:32017D0848\&from=EN. 18 May 2017

6. AMAP (2017) AMAP Assessment 2016: Chemicals of Emerging Arctic Concern. Arctic Monitoring and Assessment Programme (AMAP), Oslo, Norway. xvi+. pp 353. https://www.amap.no/documents/downl oad/3003/inline

7. Tornero V, Hanke G (2017) Potential chemical contaminants in the marine environment. An overview of main contaminant lists European Commission Joint Research Center, Ispra, Italy. ISBN 978-92-79-77045-6, EUR 28925, https://doi.org/10.2760/337288. https://publications.jrc.ec.europ a.eu/repository/bitstream/JRC108964/potential_chemical_contaminan ts_in_the_marine.pdf

8. ICES (2017) ICES advice on selection and deselection of hazardous substances of concern International Council for the Exploration of the Sea. http://ices.dk/sites/pub/Publication\%20Reports/Advice/2017/Speci al_requests/ospar.2017.21.pdf

9. Sverko E, Tomy GT, Reiner EJ, Li YF, McCarry BE, Arnot JA, Law RJ, Hites RA (2011) Dechlorane plus and related compounds in the environment: a review. Environ Sci Technol 45:5088-5098

10. UNEP (2020) Stockholm Convention. Website of the United Nations Environment Programme. http://www.pops.int/TheConvention/ThePO PS/TheNewPOPs/tabid/2511/Default.aspx

11. Government of Canada (2019) Dechlorane Plus (DP). Website of the Government of Canada. https://www.canada.ca/en/health-canada/servi ces/chemical-substances/fact-sheets/chemicals-glance/declorane-plus. html

12. Government of Canada (2016) Draft screening assessment-certain organic flame retardants substance-dechlorane plus (DP) Grouping, Environment and Climate Change Canada, Health Canada. http://www. ec.gc.ca/ese-ees/default.asp?lang=En\&n=FDE6572D-1

13. Schlabach M, Remberger M, Brorstrom-Lunden E, Norström K, Kaj L, Andersson H, Herzke D, Borgen A, Harju M (2011) Brominated flame retardants (BFR) in the Nordic environment. TemaNord 2011:528 Nordic Council of Ministers, Copenhagen. pp 86. https://read.nordic-ilibrary. org/environment/brominated-flame-retardants-bfr-in-the-nordic-envir onment_tn2011-528\#page3

14. EC (2006) Regulation (EC) No 1907/2006 of the European Parliament and of the Council of 18 December 2006 concerning the Registration, Evaluation, Authorisation and Restriction of Chemicals (REACH), establishing a European Chemicals Agency, amending Directive 1999/45/ EC and repealing Council Regulation (EEC) No 793/93 and Commission Regulation (EC) No 1488/94 as well as Council Directive 76/769/EEC and Commission Directives 91/155/EEC, 93/67/EEC, 93/105/EC and 2000/21/ EC, Official Journal of the European Union, L 396/1. https://eur-lex.europ a.eu/legal-content/en/TXT/?qid=1532936325230\&uri=CELEX:02006 R1907-20180509. Accessed 30 Dec 2006

15. ECHA (2017) Annex XV Report. Proposal for identification of a Substance of Very High Concern on the basis of the criteria set out in REACH Article 57. Identification of dechlorane Plus as SVHC, European Chemicals Agency (ECHA), Helsinki, Finland. https://echa.europa.eu/docum ents/10162/2b729df8-a54f-1485-f77b-185457d96fbd

16. EC (2003) Directive 2003/11/EG of the European Parliament and of the Council of 6 February 2003 amending for the 24th time Council Directive 76/769/EEC relating to restrictions on the marketing and use of certain dangerous substances and preparations (pentabromodiphenyl ether, octabromodiphenyl ether), Official Journal of the European Union, L42/45. http://eur-lex.europa.eu/LexUriServ/LexUriServ.do?uri=OJ:L:2003: 042:0045:0046:EN:PDF. Accessed 15 Feb 2003

17. EC (2017) Commission Regulation (EU) 2017/227 of 9 February 2017 amending Annex XVII to Regulation (EC) No 1907/2006 of the European Parliament and of the Council concerning the Registration, Evaluation, Authorisation and Restriction of Chemicals (REACH) as regards bis(pentabromophenyl)ether, Official Journal of the European Union, L35/6. https://eur-lex.europa.eu/legal-content/EN/TXT/?uri=urise rv:OJ.L_.2017.035.01.0006.01.ENG. Accessed 10 Feb 2017

18. Covaci A, Harrad S, Abdallah MA, Ali N, Law RJ, Herzke D, de Wit CA (2011) Novel brominated flame retardants: a review of their analysis, environmental fate and behaviour. Environ Int 37:532-556

19. EFSA (2012) EFSA panel on contaminants in the food chain (CONTAM); scientific opinion on emerging and novel brominated flame retardants (BFRs) in food, EFSA J 10(10):2908:1-133. https://www.efsa.europa.eu/de/ efsajournal/pub/2908

20. Möller A (2012) Alternative Halogenated Flame Retardants versus PBDEs in the Global Marine Environment-Occurrence, Distribution and Long-Range Atmospheric Transport toward the Polar Regions Leuphana Universität Lüneburg, Germany. http://opus.uni-lueneburg.de/opus/vollt exte/2013/14247/pdf/Dissertation_AxelMoeller.pdf, pp 254

21. KEMI (2015) Occurrence and use of highly fluorinated substances and alternatives, Swedish chemicals agency. pp 112. http://www.kemi.se/en/ global/rapporter/2015/report-7-15-occurrence-and-use-of-highly-fluor inated-substances-and-alternatives.pdf

22. Wang Z, Cousins IT, Scheringer M, Buck RC, Hungerbühler K (2014) Global emission inventories for C4-C14 perfluoroalkyl carboxylic acid (PFCA) homologues from 1951 to 2030, Part I: production and emissions from quantifiable sources. Environ Int 70:62-75

23. HEPA (2018) PFAS National Environmental Management Plan, Heads of EPAs Australia and New Zealand. pp 48. https://www.epa.vic.gov.au/ PFAS NEMP

24. McLachlan MS (2018) Can the Stockholm convention address the spectrum of chemicals currently under regulatory scrutiny? Advocating a more prominent role for modeling in POP screening assessment. Environ Sci Process Impacts 20:32-37

25. Jones PD, Hu W, De Coen W, Newsted JL, Giesy JP (2003) Binding of perfluorinated fatty acids to serum proteins. Environ Toxicol Chem 22:2639-2649

26. Martin JW, Mabury SA, Solomon KR, Muir DC (2003) Bioconcentration and tissue distribution of perfluorinated acids in rainbow trout (Oncorhynchus mykiss). Environ Toxicol Chem 22:196-204

27. Conder JM, Hoke RA, De WolfW, Russell MH, Buck RC (2008) Are PFCAs bioaccumulative? A critical review and comparison with regulatory criteria and persistent lipophilic compounds. Environ Sci Technol 42:995-1003

28. Wang Z, DeWitt JC, Higgins CP, Cousins IT (2017) A never-ending story of per- and polyfluoroalkyl substances (PFASs)? Environ Sci Technol 51:2508-2518

29. Brendel S, Fetter E, Staude C, Vierke L, Biegel-Engler A (2018) Short-chain perfluoroalkyl acids: environmental concerns and a regulatory strategy under REACH. Environ Sci Eur 30:9

30. UNEP (2006) Stockholm Convention. Report of the Persistent Organic Pollutants Review Committee on the work of its second meeting. Addendum. Risk profile on perfluorooctane sulfonate. SC UNEP/POPS/ POPRC.2/17/Add.5, United Nations Environment Programme. Geneva, Switzerland. http://chm.pops.int/TheConvention/POPsReviewCommi ttee/Reports/tabid/2301/Default.aspx

31. ATSDR (2018) Toxicological profile for perfluoroalkyls. U.S. Depatment of Health and Services, Agency for Toxic Substances and Disease Registry. pp 852. https://www.atsdr.cdc.gov/toxprofiles/tp200.pdf

32. EC (2006) Directive 2006/122/EC of the European Parliament and of the Council of 12 December 2006 amending for the 30th time Council Directive 76/769/EEC on the approximation of the laws, regulations and administrative provisions of the Member States relating to restrictions on the marketing and use of certain dangerous substances and preparations (perfluorooctane sulfonates), Official Jounal of the European Union, L372/32. http://eur-lex.europa.eu/LexUriServ/LexUriServ.do?uri=OJ:L:200 6:372:0032:0034:en:PDF. Accessed 27 Dec 2006

33. EC (2017) Commission Regulation (EU) 2017/1000 of 13 June 2017 amending Annex XVII to Regulation (EC) No 1907/2006 of the European 
Parliament and of the Council concerning the Registration, Evaluation, Authorisation and Restriction of Chemicals (REACH) as regards perfluorooctanoic acid (PFOA), its salts and PFOA-related substances, Official Journal of the European Union. L 150/14. https://eur-lex.europa.eu/legal -content/EN/TXT/PDF/?uri=CELEX:32017R1000\&from=EN. Accessed 14 July 2017

34. Danish Environmental Protection Agency (2014) Siloxanes (D3, D4, D5, D6, HMDS) - Evaluation of health hazards and proposal of a health-based quality criterion for ambient air. Environmental project No. 1531, 2014, Danish Environmental Protection Agency. pp 84. https://www2.mst.dk/ Udgiv/publications/2014/01/978-87-93026-85-8.pdf

35. EC (2018) Commission Regulation (EU) 2018/35 of 10 January 2018 amending Annex XVII to Regulation (EC) No 1907/2006 of the European Parliament and of the Council concerning the Registration, Evaluation, Authorisation and Restriction of Chemicals (REACH) as regards octamethylcyclotetrasiloxane ('D4') and decamethylcyclopentasiloxane ('D5'), Official Journal of the European Union, L 6/45. https://eur-lex.europ a.eu/legal-content/EN/TXT/PDF/?uri=CELEX:32018R0035\&from=EN. Accessed 11 Jan 2018

36. Lee D, Ahn C, An BS, Jeung EB (2015) Induction of the Estrogenic Marker Calbindn-D(9)k by Octamethylcyclotetrasiloxane. Int J Environ Res Public Health 12:14610-14625

37. Umweltprobenbank (2020) Umweltprobenbank des Bundes. Website of the German Environmental Specimen Bank. German Envornment Agency, Dessau-Roßlau. https://www.umweltprobenbank.de/en/docum ents

38. Rüdel H, Lepper P, Steinhanses J, Schröter-Kermani C (2003) Retrospective monitoring of organotin compounds in marine biota from 1985 to 1999: results from the German Environmental Specimen Bank. Environ Sci Technol 37:1731-1738

39. Fliedner A, Rüdel H, Knopf B, Lohmann N, Paulus M, Jud M, Pirntke U, Koschorreck J (2018) Assessment of seafood contamination under the marine strategy framework directive: contributions of the German environmental specimen bank. Environ Sci Pollut Res Int 25:26939-26956

40. Federal Environment Agency Berlin (2008) German Environmental Specimen Bank-Concept, Berlin. pp 27. https://www.umweltprobenbank.de/ upb_static/fck/download/concept_oct_2008_en.pdf

41. Paulus M, Klein R, Teubner D (2018) German Environmental Specimen Bank: Guideline for Sampling and Sample Treatment Blue Mussel (Mytilus edulis-Complex). Standard Operating Procedure (SOP) Umweltbundesamt, Dessau-Rosslau. https://www.umweltprobenbank.de/en/docum ents/publications/26658

42. Klein R, Paulus M, Tarricone K, Teubner D (2018) German Environmental Specimen bank: Guideline for Sampling and Sample Treatment. Eelpout (Zoarces viviparus). Standard Operating procedure (SOP), Umweltbundesamt, Dessau-Rosslau. https://www.umweltprobenbank.de/en/docum ents/publications/26543

43. Rüdel H, Uhlig S, Weingärtner M (2009) German Environment Specimen Bank: Guidelines for Sampling and Sample Processing. Pulverisation and Homogenisation of Environmental Samples by Cryomilling. Standard Operating Procedure (SOP) Umweltbundesamt, Dessau-Rosslau. https:// www.umweltprobenbank.de/upb_static/fck/download/IME_SOP_prepa ration_Dez2008 V200.pdf

44. Rüdel H, Fliedner A, Kösters J, Schröter-Kermani C (2010) Twenty years of elemental analysis of marine biota within the German Environmental Specimen Bank-a thorough look at the data. Environ Sci Pollut Res Int $17: 1025-1034$

45. ECHA (2016) Substance evaluation conclusion as required by REACH Article 48 and evaluation report for 2,4,6-tribromophenol, EC No 204-278-6, CAS No 118-79-6. EC No 204-278-6, European Chemicals Agency (ECHA), Helsinki, Finland. https://echa.europa.eu/documents/10162/6e2fea36f7d 1-4e90-874f-c02ff853f6c6. pp 54

46. Hiebl J, Melcher J, Gundersen H, Schlabach M, Vetter W (2006) Identification and quantification of polybrominated hexahydroxanthene derivatives and other halogenated natural products in commercial fish and other marine samples. J Agric Food Chem 54:2652-2657

47. Vetter W, Jun W (2003) Non-polar halogenated natural products bioaccumulated in marine samples. II. Brominated and mixed halogenated compounds. Chemosphere 52:423-431
48. Vetter W, von der Recke R, Herzke D, Nygard T (2007) Natural and manmade organobromine compounds in marine biota from Central Norway. Environ Int 33:17-26

49. Covaci A, Losada S, Roosens L, Vetter W, Santos FJ, Neels H, Storelli A, Storelli MM (2008) Anthropogenic and naturally occurring organobrominated compounds in two deep-sea fish species from the Mediterranean Sea. Environ Sci Technol 42:8654-8660

50. Pena-Abaurrea M, Weijs L, Ramos L, Borghesi N, Corsolini S, Neels H, Blust R, Covaci A (2009) Anthropogenic and naturally-produced organobrominated compounds in bluefin tuna from the Mediterranean Sea. Chemosphere 76:1477-1482

51. Goeritz I, Falk S, Stahl T, Schafers C, Schlechtriem C (2013) Biomagnification and tissue distribution of perfluoroalkyl substances (PFASs) in market-size rainbow trout (Oncorhynchus mykiss). Environ Toxicol Chem 32:2078-2088

52. LAWA-AO (2016) Rahmenkonzeption Monitoring, Teil B: Bewertungsgrundlagen und Methodenbeschreibungen. Arbeitspapier IV.3. Konzeption für Biota-Untersuchungen zur Überwachung von Umweltqualitätsnormen gemäß RL 2013/39/EU. Stand. Bund/Länderarbeitsgemeinschaft Wasser (LAWA). pp 32. Accessed 27 Oct 2016

53. Neugebauer F, Dreyer A, Lohmann N, Koschorreck J (2018) Determination of halogenated flame retardants by GC-API-MS/MS and GC-EIMS: a multi-compound multi-matrix method. Anal Bioanal Chem 410:1375-1387

54. Rüdel H, Müller J, Jürling H, Bartel-Steinbach M, Koschorreck J (2011) Survey of patterns, levels, and trends of perfluorinated compounds in aquatic organisms and bird eggs from representative German ecosystems. Environ Sci Pollut Res Int 18:1457-1470

55. Rüdel H, Radermacher G, Fliedner A, Lohmann N, Duffek A (2020) A field study in support of the monitoring of priority substances in German freshwater fish: derivation of fillet-to-whole fish conversion factors. Environ Sci Eur 32:13

56. Radermacher G, Rudel H, Wesch C, Bohnhardt A, Koschorreck J (2020) Retrospective analysis of cyclic volatile methylsiloxanes in archived German fish samples covering a period of two decades. Sci Total Environ 706:136011

57. EC (2014) Guidance document no. 32 on biota monitoring: (the implementation of EQSbiota) under the Water Framework Directive. Common Implementation Strategy for the Water Framework Directive (2000/60/ EC). Technical Report - 2014 - 083. ISBN 978-92-79-44634-4, Office for Official Publications of the European Communities, Luxembourg. pp 87. https://circabc.europa.eu/sd/a/62343f10-5759-4e7c-ae2b-12677aa576 05/Guidance\%20No\%2032\%20-\%20Biota\%20Monitoring.pdf

58. Fryer RJ, Nicholson MD (1999) Using smoothers for comprehensive assessments of contaminant time series in marine biota. ICES J Mar Sci $56: 790$

59. Shen L, Reiner EJ, Helm PA, Marvin CH, Hill B, Zhang X, Macpherson KA, Kolic TM, Tomy GT, Brindle ID (2011) Historic trends of dechloranes $602,603,604$, dechlorane plus and other norbornene derivatives and their bioaccumulation potential in lake ontario. Environ Sci Technol 45:3333-3340

60. Wu JP, Zhang Y, Luo XJ, Wang J, Chen SJ, Guan YT, Mai BX (2010) Isomerspecific bioaccumulation and trophic transfer of Dechlorane Plus in the freshwater food web from a highly contaminated site, South China. Environ Sci Technol 44:606-611

61. Sühring R, Busch F, Fricke N, Kötke D, Wolschke H, Ebinghaus R (2016) Distribution of brominated flame retardants and dechloranes between sediments and benthic fish — a comparison of a freshwater and marine habitat. Sci Total Environm 542:578-585

62. Howard PH, Muir DC (2010) Identifying new persistent and bioaccumulative organics among chemicals in commerce. Environ Sci Technol 44:2277-2285

63. Nacci D, Clark B, La Guardia M, Miller K, Champlin D, Kirby I, Bertrand A, Jayaraman S (2018) Bioaccumulation and Effects of Dietary Exposure to the Alternative Flame Retardant, Bis(2-ethylhexyl) tetrabromophthalate (TBPH), in the Atlantic killifish. Fundulus heteroclitus, Environ Toxicol Chem, p 37

64. Sagerup K, Herzke D, Harju M, Evenset A, Christensen GN, Routti H, Fuglei E, Aars J, Strøm H, Gabrielsen GW (2010) New brominated flame retardants in Arctic biota Statlig program for forurensningsovervåking. Rapport 1070/2010. TA-2630/2010, External reports - EKST, NILU - Norwegian Institute for Air Research. pp 32. https://brage.bibsys.no/xmlui/bitstream/ 
handle/11250/173191/NewBrominatedFlameRetardants.pdf?seque nce $=1$ \&isAllowed $=y$

65. Kurt-Karakus PB, Muir DCG, de Jourdan B, Teixeira C, Epp Martindale J, Embers H, Wang X, Keir M, Backus S (2019) Bioaccumulation of selected halogenated organic flame retardants in Lake Ontario. Environ Toxicol Chem 38:1198-1210

66. Law K, Halldorson T, Danell R, Stern G, Gewurtz S, Alaee M, Marvin C, Whittle M, Tomy G (2006) Bioaccumulation and trophic transfer of some brominated flame retardants in a Lake Winnipeg (Canada) food web. Environ Toxicol Chem 25:2177-2186

67. Santin G, Baron E, Eljarrat E, Barcelo D (2013) Emerging and historical halogenated flame retardants in fish samples from Iberian rivers. J Hazard Mater 263(Pt 1):116-121

68. Alcock RE, Busby J (2006) Risk migration and scientific advance: the case of flame-retardant compounds. Risk Anal 26:369-381

69. Ahrens L, Bundschuh M (2014) Fate and effects of poly- and perfluoroalkyl substances in the aquatic environment: a review. Environ Toxicol Chem 33:1921-1929

70. Ahrens L, Taniyasu S, Yeung LW, Yamashita N, Lam PK, Ebinghaus R (2010) Distribution of polyfluoroalkyl compounds in water, suspended particulate matter and sediment from Tokyo Bay, Japan. Chemosphere 79:266-272

71. US EPA (2006/15) PFOA Stewardship Program. https://www.epa.gov/ assessing-and-managing-chemicals-under-tsca/risk-management-andpolyfluoroalkyl-substances-pfass, United States Environmental Protection Agency

72. Valdersnes S, Nilsen BM, Breivik JF, Borge A, Maage A (2017) Geographical trends of PFAS in cod livers along the Norwegian coast. PLOS ONE 12:e0177947

73. Danielsson S, Faxneld S, Nyberg E, Vasileiou M, Bignert A (2014) Contaminants in fish from potentially polluted sites along the Swedish coast with the national monitoring programme as reference. Report 8:2014, Swedish Museum of Natural History, Department of Environmental Research and
Monitoring, Stockholm, Sweden. pp 155. https://www.diva-portal.org/ smash/get/diva2:728476/FULLTEXT01.pdf

74. Bignert A, Danielsson S, Ek C, Faxneld S, Nyberg E (2017) Comments Concerning the National Swedish Contaminant Monitoring Programme in Marine Biota, 2017. Report no. 4:2017 Swedish Museum of Natural History, Department of Environmental Research and Monitoring, Stockholm, Sweden. pp 341. http://naturvardsverket.diva-portal.org/smash/get/ diva2:1091353/FULLTEXT01.pdf

75. Faxneld S, Danielsson S, Nyberg E (2014) Distribution of PFAS in liver and muscle of herring, perch, cod, eelpout, arctic char, and pike from limnic and marine environments in Sweden. Report no 9:2014, Swedish Museum of Natural History, Department of Environmental Research and Monitoring, Stockholm, Sweden. pp. 33. https://www.diva-portal.org/ smash/get/diva2:767385/FULLTEXT01.pdf

76. Junttila V, Vähä E, Perkola N, Räike A, Siimes K, Mehtonen J, Kankaanpää H, Mannio J (2019) PFASs in Finnish rivers and fish and the loading of PFASs to the Baltic Sea. Water 11:870

77. Powell DE, Schoyen M, Oxnevad S, Gerhards R, Bohmer T, Koerner M, Durham J, Huff DW (2018) Bioaccumulation and trophic transfer of cyclic volatile methylsiloxanes (CVMS) in the aquatic marine food webs of the Oslofjord, Norway. Sci Total Environ 622-623:127-139

78. Kierkegaard A, Bignert A, McLachlan MS (2013) Cyclic volatile methylsiloxanes in fish from the Baltic Sea. Chemosphere 93:774-778

79. UNEP (2009) Stockholm Convention. The new POPs under the Stockholm Convention, United Nations Environmental Programme. Geneva, Switzerland. http://chm.pops.int/Convention/ThePOPs/TheNewPOPs/tabid /2511/Defaultaspx

\section{Publisher's Note}

Springer Nature remains neutral with regard to jurisdictional claims in published maps and institutional affiliations.

\section{Submit your manuscript to a SpringerOpen ${ }^{\circ}$ journal and benefit from:}

- Convenient online submission

- Rigorous peer review

- Open access: articles freely available online

- High visibility within the field

- Retaining the copyright to your article

Submit your next manuscript at $\boldsymbol{\nabla}$ springeropen.com 